\title{
Computer Aided System for Manufacturing Industries Economic Production Status Determination
}

\author{
Basil Olufemi Akinnuli1 ${ }^{*}$, Eugene C. Kalu-Imo', Anakobe Jimoh Yakubu² \\ ${ }^{1}$ Department of Mechanical Engineering, Federal University of Technology, Akure, Nigeria \\ ${ }^{2}$ Department of Computer Engineering, Federal Polytechnic, Ile-Oluji, Nigeria \\ Email: ^ifembola@yahoo.com,yakubqiblah@yahoo.com
}

How to cite this paper: Akinnuli, B.O., Kalu-Imo, E.C. and Yakubu, A.J. (2018) Computer Aided System for Manufacturing Industries Economic Production Status Determination. Open Access Library Journal, 5: e4133.

https://doi.org/10.4236/oalib.1104133

Received: November 8, 2017

Accepted: January 8, 2018

Published: January 11, 2018

Copyright $\odot 2018$ by authors and Open Access Library Inc.

This work is licensed under the Creative Commons Attribution International License (CC BY 4.0).

http://creativecommons.org/licenses/by/4.0/

\begin{abstract}
Performance status has to do with profitability of manufacturing industries. Good performance brings about increase in productivity. There are in existence different models and software, but none has been able to develop software based on American Productivity Center model (APC). The strategic decisions required were identified as: Factor Productivity, Price Recovery and Cost Effectiveness indices, while the parameters used are: quantity produced, price per unit, labour input time, cost per hour of labour as well as the period. These were used to develop the models for the strategic decisions mentioned and software (PPE-INDICES, 2016) for implementation of the models using Java programming language. Olam cocoa processing company was used as the case study and the software was able to report the performance of the company thus: $24 \%, 51 \%$ and $87 \%$ increase in Factor Productivity, Price Recovery and Cost Effectiveness indices respectively for period 2013/2014, 29\%, 20\% and 55\% increase in Factor Productivity, Price Recovery and Cost Effectiveness indices respectively for period 2014/2015, and 23\%, 13\% and 39\% increase in Factor Productivity, Price Recovery and Cost Effectiveness indices respectively for period 2015/2016. The model and its software will find its application in all manufacturing industries of developing and developed countries.
\end{abstract}

\section{Subject Areas \\ Industrial Engineering}

\section{Keywords}

Computer Aided System, Economic Productivity Determination, Manufacturing Industries 


\section{Introduction}

In the development literature, industrialization has been accepted as the major driving force of the modern economy. In most modern economies, industrial sector serves as the vehicle for the production of goods and services, the generation of employment and the enhancement of incomes. Hence, [1] [2] [3] [4] described industry and in particular the manufacturing sub-sector, as the heart of the economy.

In the light of the above, Nigeria has employed several strategies which were aimed at enhancing the productivity of the sector in order to bring about economic growth and development. For instance, the country adopted the import substitution industrialization strategy during the First National Development Plan (1962-1968) which aimed at reducing the volume of imports of finished goods and encouraging foreign exchange savings by producing locally some of the imported consumer goods, Central bank of Nigeria [5]. The country consolidated her import substitution industrialization strategy during Second National Development Plan period (1970-74) which actually fell within oil boom era. At this time, manufacturing activities were so organized to depend on imported inputs because of the weak technological base of the economy. However, as a result of the collapse of the world oil market in the early 1980s, there was a severe reduction in the earnings from oil exports. Consequently, the import-dependent industrial structure that had emerged became unsustainable owing to the paucity of earnings from oil exports which could not adequately pay for the huge import bills, Central Bank of Nigeria [5]. Various policy measures were adopted to ameliorate the above situation, such as the stabilization measures of 1982, the restrictive monetary policy and stringent exchange control measures of 1984, all proved abortive. This led to the introduction of the Structural Adjustment Program (SAP) in 1986 Central bank of Nigeria [5]. One of the main reasons for the introduction of SAP was to reduce the high dependence of the economy on crude oil as the major foreign earner, by promoting non-oil exports, particularly manufactured goods. But the contribution of the manufacturing sub-sector to GDP has declined steadily, due to a number of factors Central bank of Nigeria [5]. As a result, government introduced many other economic policies. Despite these efforts of the government, the performance of the manufacturing sectors is still not clear. The study therefore seeks to develop a software model that will determine the economic productivity performance of manufacturing industries for sustainable economic development.

\section{Literature Review}

There are many definitions attached to productivity by many authors like: [6]-[14]. In industrial engineering, productivity is generally defined as the relation of output (i.e. produced goods) to input (i.e. consumed resources) in the manufacturing transformation process. However, there are numerous variations on this basic ratio which is often too wide, a definition to be useful in practice. 
Examining the term from different perspectives, [11] summarize a number of these variations found in different literatures. The basic content seems to be the same in many definitions of productivity. However, within the similar definitions, there are three broad categorizations which are: the technological engineering and economics concepts used in its [15] [16] [17].

Although the definition of productivity appears straight forward, for three major reasons it is difficult to deal with [18]; [19] and [20]. According to [21], the overall performance of a company is comprised of at least seven criteria: effectiveness, efficiency, quality, productivity, quality of work life, innovations, and profitability. Productivity is thus a key success factor for all companies. [22] [23] [24] and [25] has stated that organizations must be able to continuously increase their productivity in order to stay profitable.

Productivity combines the concepts of effectiveness and efficiency, where effectiveness is the degree to which end results are achieved to the required standard [26] [27] and [28]. Growth is a function of total factor productivity (TFP), which is the aggregation of partial productivities [29] [30] and [31].

Conceptually, output embodies both quality and quantity and this creates sometimes confusion that the productivity measure is unfounded in the sense that they do not take quality into consideration. Such arguments may be true in case of very simple productivity ratios. In those ratios, the quality of the output or input is often ignored. But, when the output is measured in deflated net sales, for example, the quality of the products or services is included in the function. However, quantifying quality changes in productivity measurement is always a measurement problem, not a conceptual problem. At the conceptual level quality of the output and the input are very much included in the productivity ratio.

\section{Methodology}

The following are the methods used to achieve the objectives in this research which are: ascertain the required parameters for the model development, mathematical models used for the required computation of each parameter, development of algorithm and its software for implementing the mathematical models ascertained, application of the models and the developed software named (PPE-INDICES 2016).

\subsection{Identification of Required Parameters for the Model Development}

The following parameters for strategic decision taken were identified in this research for required model development:

1) Quantity produced in year. This is the total unit or quantity of product produced in either the base year or current year. It is an output function.

2) Price per Unit for product. This function is used to convert the output in to monetary form. It is the cost of each unit of the product.

3) Labour input time: This is an input function that describes the time input 
of labour to produce the given output quantity of the product.

4) Cost per hour of labour. This is the amount paid per hour for the labour used to produce the given quantity of product.

5) Period of time: This is the time under consideration which could be either a base year or a current year. The base year is the period used as a comparison time to determine the economic productivity of a current year relative to the base year.

6) Factor Productivity Index (FPI): This defined as the ratio of the value of current level output to base level output, divided by the ratio of the value of current-period inputs to base level inputs. The productivity change ratio measures the technical efficiency of firms.

7) Price recovery index. This defined as the ratio of the value of outputs at current period prices to the value at base level prices, divided by the value of inputs at current period prices to the value at base level prices. The price recovery ratio helps measure the abilities of firms to be price or allocative efficient.

8) Cost Effectiveness index: This is the ratio the value change of input to the value change of total output.

\subsection{Case-Study History}

Data used for this study were extracted from accounting/inventory departments of Olam Cocoa Processing Company Akure. Olam is a leading global integrated supply chain manager and processor of agricultural products and food ingredients. Agricultural products processed by Olam include Cocoa, Cashew, Sesame and Cotton. It also has a cashew processing plant at Ogbondoroko, a suburb of Ilorin, Kwara state. According to the statement, working closely with the group, Olam's corporate responsibility and sustainability team had delivered farm management training and GPS mapped 5000 hectares of farmland. "In so doing, Olam equipped Nigerian cocoa farmers with accurate information about the size of their farms", it added. The company also distributed higher yielding planting materials and successfully prepared the farmers for Rainforest Alliance audits in 2012 and 2013 which made the N26 million premium payments possible [32].

The company is located besides Ondo State Cooperative building, Akure-Owo express road. The Company has over 50 workers both skilled and unskilled.

\subsection{Nomenclature for Model Development}

1) $Q_{1}=$ Quantity produced in year 1

2) $Q_{2}=$ Quantity produced in year 2

3) $P_{1}=$ price per units for product in year 1

4) $P_{2}=$ price per units for product in year 2

5) $I_{1}=$ Labour (input) time in year 1

6) $I_{2}=$ Labour (input) time in year 2

7) $C_{1}=$ Cost per hour of Labour (input) time in year 1

8) $C_{2}=$ Cost per hour of Labour (input) time in year 2 
9) $T_{1}=$ Period of time in year 1

10) $T_{2}=$ Period of time in year 2

\subsection{Development of Algorithm for Implementing the Mathematical Mode}

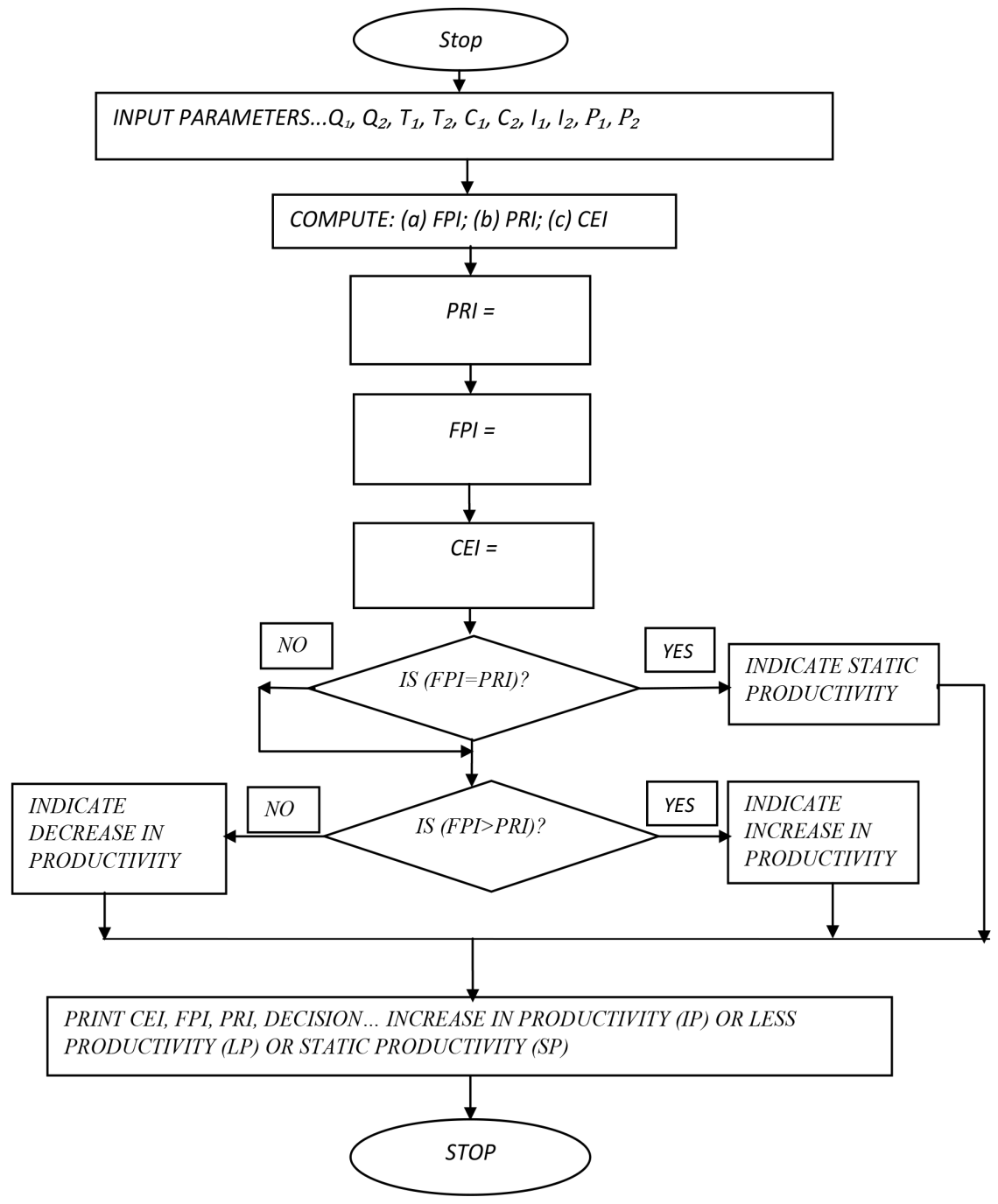

Figure 1. Software algorithm.

\subsection{Software Development}

This software was developed using the java application, and intended to determine the production status of manufacturing industries regardless of the product type. Once the data is extracted in this manner, the cumbersomeness of manual calculation is eliminated by the use of this software and the production status is determined in matter of a second. This makes this software a handy to for manager and business owners.

\subsection{Software Requirement}

Below are conditions that must be met or processed by a system to satisfy the 
specification for this software.

1) Microsoft window 98 or above (Operating System Platform)

2) Browser

3) Java Compiler (JDK 1.5 above)

\subsection{Hardware Requirement}

The hardware requirements are:

1) System with minimum of Pentium II motherboard

2) Minimum of 5 gigabyte of Hard disk drive

3) A good VGA or SVGA monitor

4) Printer.

\subsection{Software Interface}

The software interface designed for the determination of economic productivity of a firm of product is as shown in Figure 1. Loading this option and keying in the appropriate data will perform the desired computation and generate the result in no time at all. This interface is designed to display input data such as quantity produced, price per unit, labour time, labour time 2, Time of production, cost per hour of labour and cost 2 per hour of labour and when these data is inputted it yields an output displayed as factor productivity price recovery index cost effectiveness index and then a decision which is either increase in productivity, decrease in productivity or a static productivity.

\subsection{Application of Developed Software}

For the purpose of application of the developed software, the necessary data was collected from Olam Cocoa Processing Company Akure.

\subsection{Data Collected For Model Application}

The data for applying the APC model was obtained from the accounting/ inventory departments of Olam Cocoa Processing Company Akure (2013/2014) fiscal year. This data made it possible to calculate the deflated values, change ratios, performance ratios and performance contributions. Quantities; prices and/or values of both input and output were obtained. The period selected was 2013 to 2016 fiscal year.

\subsection{Application of Developed Software (PPE-INDICES 2016)}

The software interface designed for the determination of economic productivity of a firm of product is as shown in Figures 2-4. When the data in Table 1 to Table 3 is inputted into the software appropriately, it generate results as shown in the interfaces Figure 4. The result interface is designed to include inputted date, Factor productivity index, and price recovery index and cost effectiveness index.

This interface accepts all required data from Table 2 for the 2014/2015 fiscal year. Here, 2015 is compared to 2014 as the base year and the software 
Table 1. Extracted from accounting/inventory departments of Olam Cocoa Processing Company Akure (2013/2014) fiscal year.

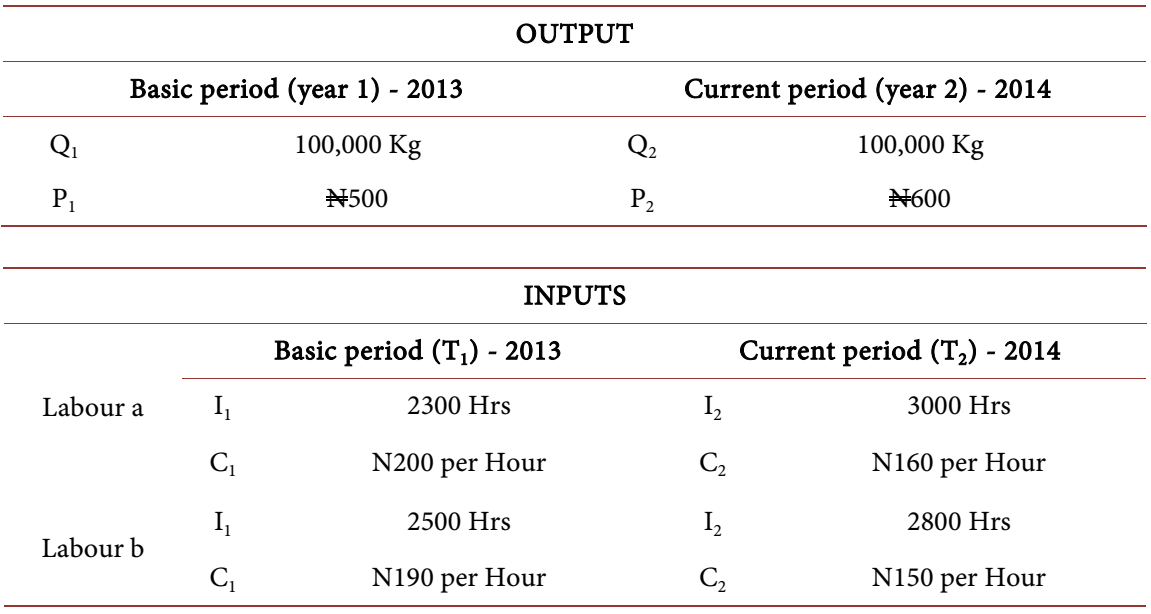

Table 2. Extracted from accounting/inventory departments of Olam Cocoa Processing Company Akure (2014/2015) fiscal year.

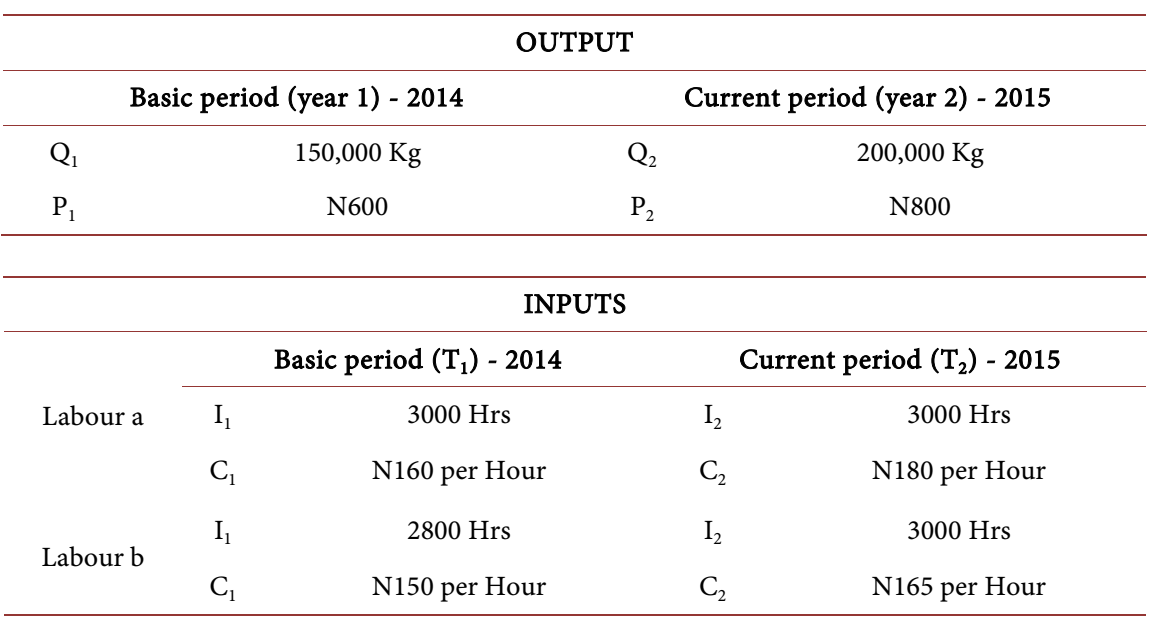

Table 3. Extracted from accounting/inventory departments of Olam Cocoa Processing Company Akure (2015/2016) fiscal year.

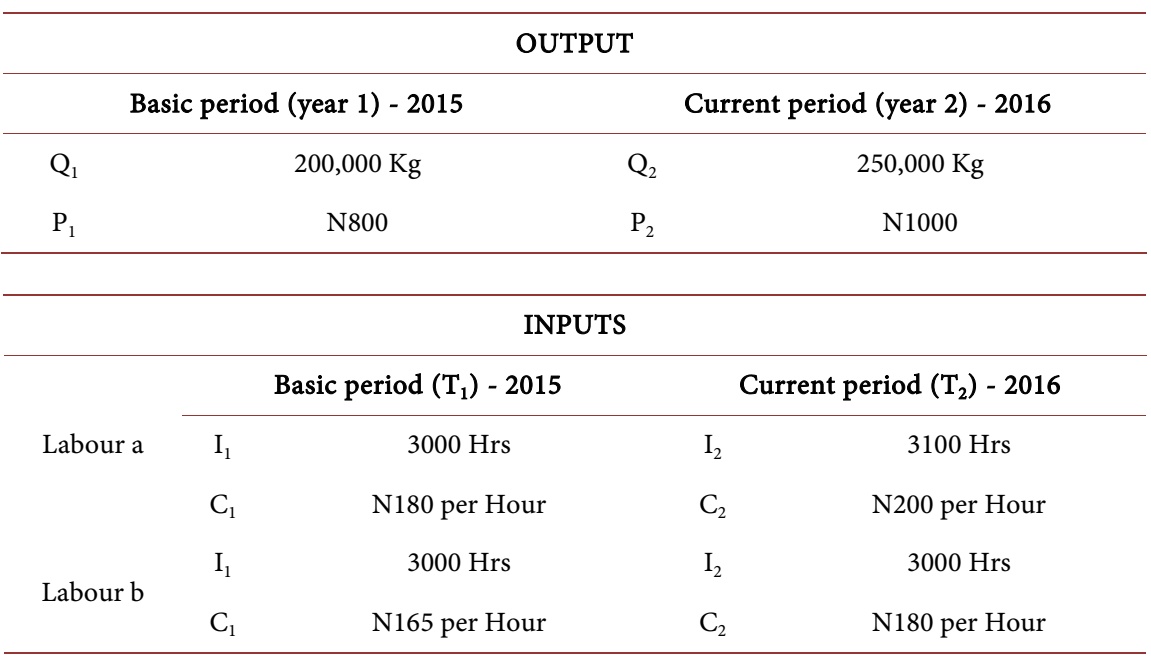




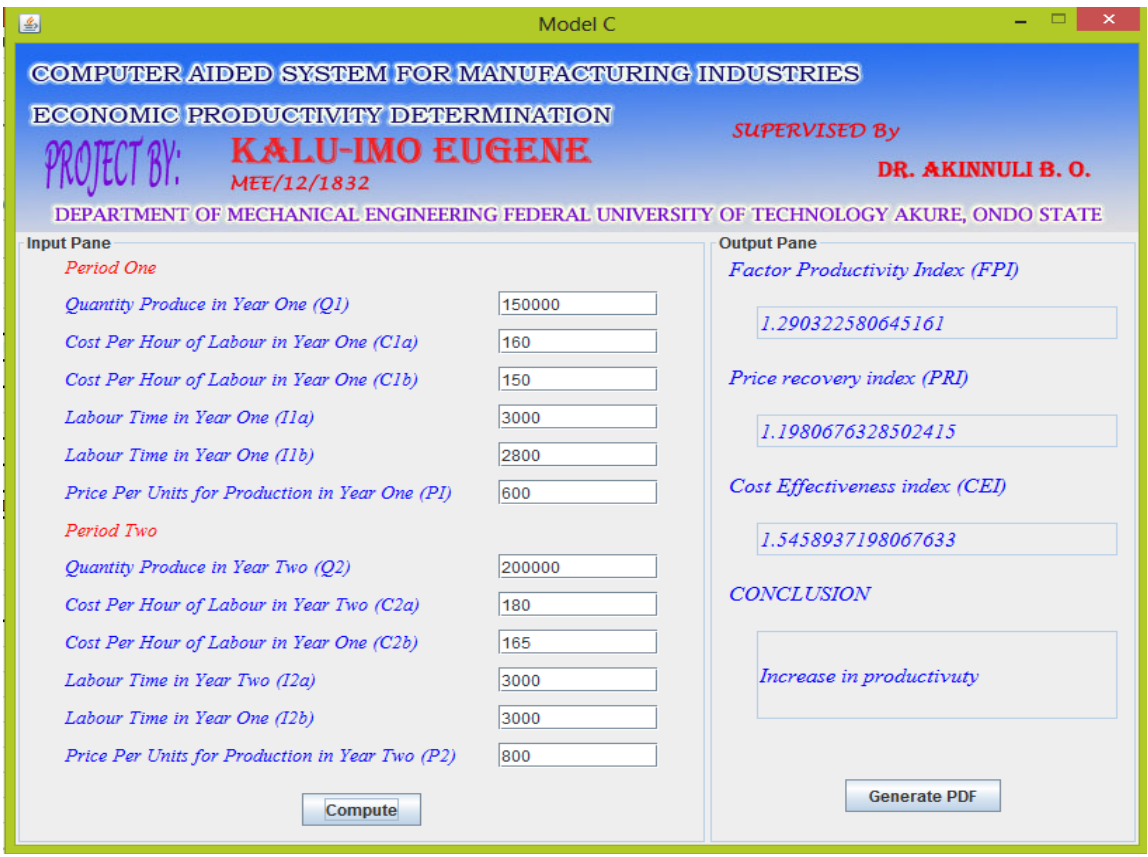

Figure 2. Interface for software application to Table 2 data.

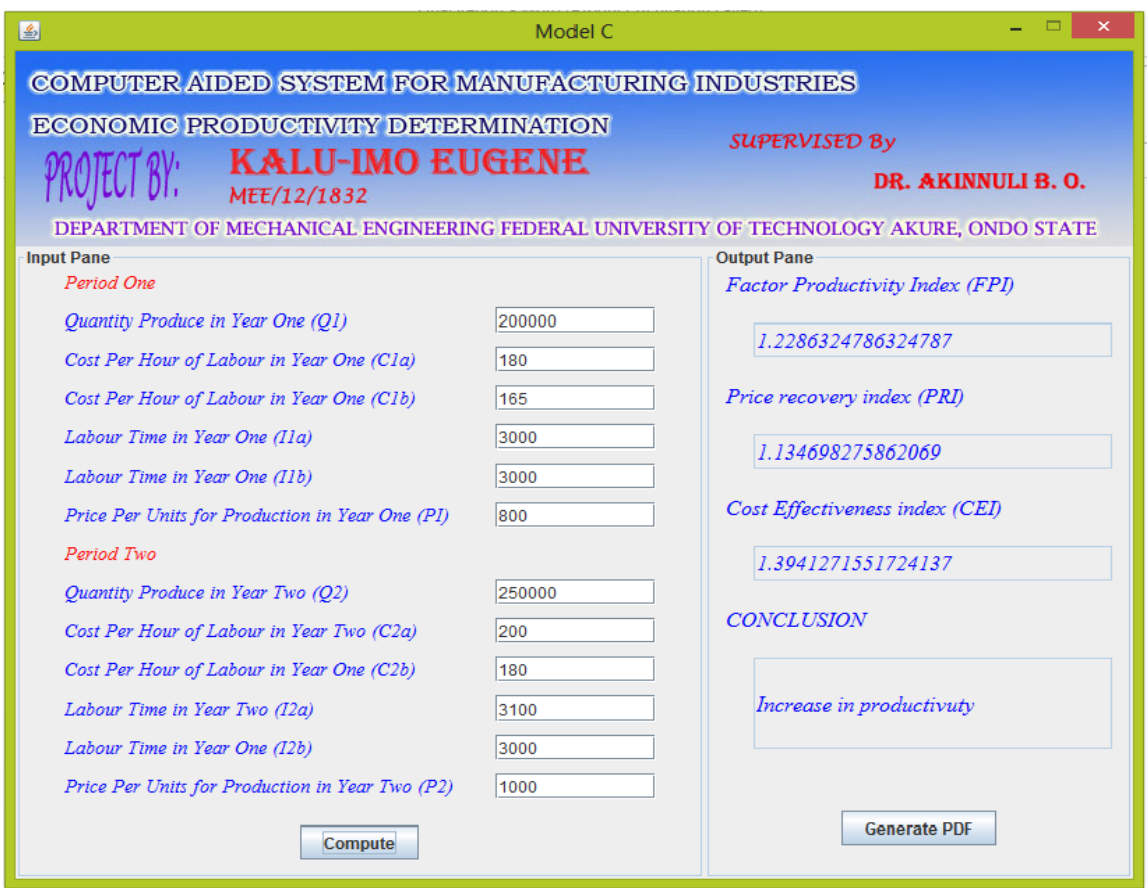

Figure 3. Interface for software application to Table 3 data.

(PPE-INDICES 2016) was able to indicate an increase in productivity bases in the data inputted.

This interface accepts all required data from Table 3 for the 2013/2014 fiscal year. Here, 2016 is compared to 2015 as the base year and the software (PPE-INDEX 2016) was able to indicate a decrease in productivity bases in the data inputted. 


\subsection{Developed Software (PPE-INDICES 2016) Cost}

The cost implication for PPE-INDICES, 2016 development is as shown in Table 4.

From the above cost implication for (PPE-INDICES 2016), a unit cost for the software disk is N100,000.00. Similar software like the SANDVIK CORAMANT-PAYBACK CALCULATOR cost \$10. By using (PPE-INDICES 2016) the establishment would have added a $50 \%$ economic value.

\subsection{Maintenance of Software (PPE-INDICES 2016) Developed}

For the preservation of this software, it is important to:

1) Keep it away from direct sun light.

2) Keep it away from dust.

3) Store in a dry environment.

4) Avoid exposure to magnetic fields.

5) Avoid using on virus infested system.

\section{Result and Discussion}

Results identifies APC model as a suitable model for making strategic decision required for measuring the productivity in manufacturing industries in that it can make use of both financial and non-financial data as input data. The algorithm now was used to develop software (PPE- INDICES 2016) with the capability of calculating the economic productivity of any manufacturing firm. Case study data was used to run PPE-INDICES 2016 and the results gotten were as desired.

The software was able to compute the three performance measuring indicators which are the factor productivity index, price recovery index and cost effectiveness index for the various period under consideration. The results are displayed on a printable software interface as shown in Figure 2 to Figure 4 in chapter three.

PPE-INDICES 2016 was verified by comparison of manual application result of the model and the results from PPE-INDICES 2016 and were tabulated in Table results 1, 2 and 3 respectively. From the table it is concluded that PPE-INDICES 2016 is not only accurate, but also convenient and can produce the desired result in no time at all. These features make PPE-INDICES 2016 a

Table 4. Development of software cost.

\begin{tabular}{ccc}
\hline S/n & Description & Estimated Cost $(\mathrm{N})$ \\
\hline 1 & Coding, Debugging and test running & $30,000.00$ \\
2 & Program compilation & $5,000.00$ \\
3 & Production of installable program & $1,000.00$ \\
4 & Miscellaneous & $3,000.00$ \\
TOTAL & & $39,000.00$ \\
\hline
\end{tabular}




\section{PERFORMANCE INDICATOR}

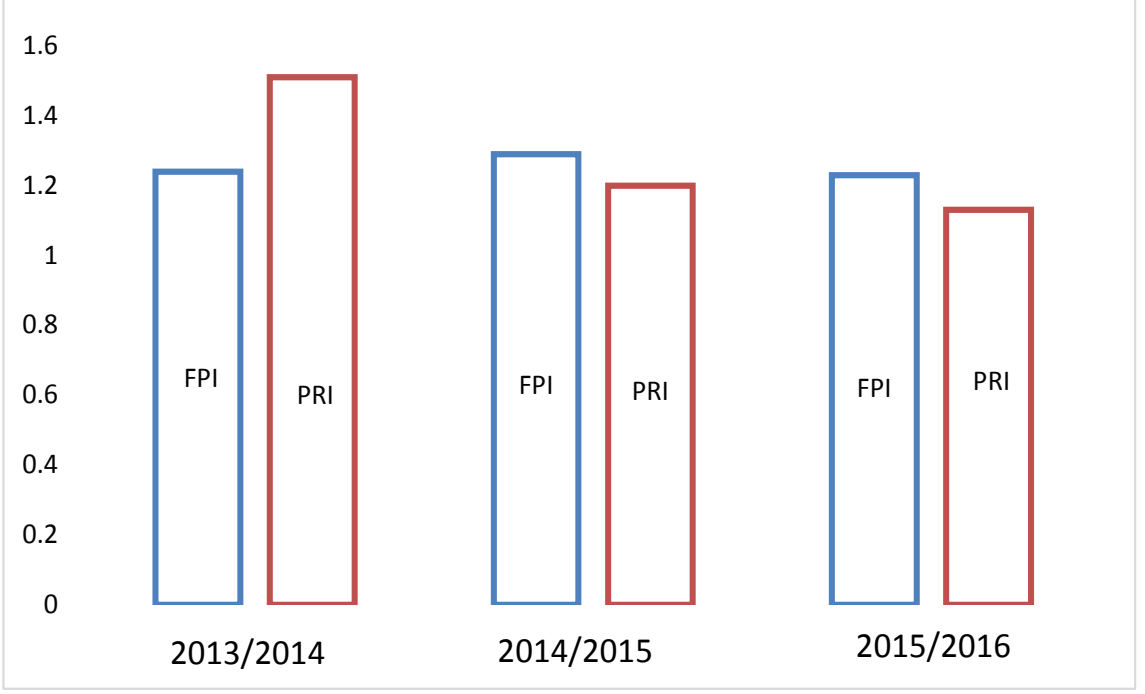

Figure 4. Productivity performance graph.

recommended handy tool for managers and any other performance decision maker in the manufacturing industry.

Table 5 to Table 7 show the results of the manual and software application of the model. The deviation of the software application from manual application authenticates the accuracy of the software.

\section{Discussion}

From the result as determined with the software, it is easy to see the performance of the company within the selected period. The result for $(2013 / 2014)$, with 2013 as base year shows that CEI $=$ FPI $\times$ PRI i.e. $1.87=1.24 \times 1.51$. This index indicates also that sales revenue is increasing faster than the cost and that the product price increase is more significant than productivity. So there is low productivity.

The indices for $(2014 / 2015)$ CEI $=$ FPI $\times$ PRI i.e. $1.55=1.29 \times 1.20$ indices also indicates that sales revenue is increasing faster than the cost and that the productivity is more significant than the product price increase So there is increase in productivity. The indices for $(2015 / 2016)$ which is CEI $=$ FPI $\times$ PRI i.e. $1.39=1.23 \times 1.13$ also indicate that sales revenue is increasing faster than the cost and that the productivity is more significant than the product price increase so there is increase in productivity (Table 8).

The graph shows the performance indicators for the various years compared. From the graph it can be seen that period 2013/2014 recorded a low productivity level that is FPI $<$ PRI hence price recovery was more significant. From the same graph, the year 2014/2015 and 2015/2016, FPI > PRI, these shows increase an productivity of the company. 
Table 5. 2013/2014 Manual/Software results.

\begin{tabular}{cccc}
\hline \multicolumn{3}{c}{ 2013/2014 } \\
\hline Performance Indicators & Manual Result & Software Result & Deviation \\
\hline FPI & 1.24 & 1.24 & Nil \\
PRI & 1.51 & 1.51 & Nil \\
CEI & 1.87 & 1.87 & Nil \\
\hline
\end{tabular}

Table 6. 2014/2015 Manual/Software results.

\begin{tabular}{cccc}
\hline \multicolumn{3}{c}{$2014 / 2015$} \\
\hline Performance Indicators & Manual Result & Software Result & Deviation \\
\hline FPI & 1.29 & 1.29 & Nil \\
PRI & 1.30 & 1.20 & Nil \\
CEI & 1.55 & 1.55 & Nil \\
\hline
\end{tabular}

Table 7. 2015/2016 Manual/Software results.

\begin{tabular}{cccc}
\hline & \multicolumn{2}{c}{$2015 / 2016$} & \\
\hline Performance Indicators & Manual Result & Software Result & Deviation \\
\hline FPI & 1.23 & 1.23 & Nil \\
PRI & 1.13 & 1.51 & Nil \\
CEI & 1.39 & 1.87 & Nil \\
\hline
\end{tabular}

Table 8. Tabulation of performance indices.

\begin{tabular}{ccccccc}
\hline S/n & Year & FPI & PRI & CEI & DECISION & REMARK STATUS \\
\hline 1 & $2013 / 2014$ & 1.24 & 1.51 & 1.87 & EPI $<$ PRI & Low Productivity \\
2 & $2014 / 2015$ & 129 & 1.20 & 1.55 & EPI $>$ PRI & Increases Productivity \\
3 & $2015 / 2016$ & 1.23 & 1.13 & 1.39 & EPI $>$ PRI & Increases Productivity \\
\hline
\end{tabular}

\section{Conclusions}

The impetus for this study arose from the review of the literature on importance of productivity measurement in the manufacturing industries. This literature review revealed that productivity can be measured by a profit-linked model, and this model can be set up and computed using this software. American Productivity Center (APC) Model was found to be the most suitable; it allows for measure of both non-financial (indexes) and financial (Naira) during computation. The non-financial and financial measurement allows both line manager and financial manager to use the model for measuring productivity and profitability in the company.

The computation with the model software makes it possible for the manager to get further insight on the performance of the firm in no time at all. 
In addition, the literature revealed productivity which is regarded as value addition and quality, which is value enhancement, is the main determinant of competitiveness. To remain competitive, companies need to integrate and synergize both productivity and quality.

Based on the review of literature, the main objectives of this study were formulated as follows: to identify the strategic decision required for measuring the productivity in manufacturing industries, identify and adopting a suitable model for measuring economic productivity in manufacturing industries, develop an algorithm and software that will calculate the economic productivity of any manufacturing industry based on the mathematical relations of the identified model, and then validate the software (PPE IDICES 2016).

In accordance with the aforementioned objectives, a literature study APC model was set up and productivity, price recovery and profitability were computed with the software.

This study could be classified as being successful because a suitable productivity measurement was computed and contribution of profitability were decomposed to productivity and price recover to determine the economic productivity of Olam cocoa processing company Akure.

From the discussion, the result indicates that Olam cocoa processing company Akure experienced a low productivity in 2014 compared to 2013 as the base year. Subsequently, 2015 and 2016 were better years for her as productivity improved.

\section{References}

[1] Kayode, M.O. (1989) Nigeria since Independence: The First 25 Years. Heinemann Books Ltd., Ibadan.

[2] Al-Darrab, I. (2000) Relationships between Productivity, Efficiency, Utilisation and Quality. Work Study, 49, 97-103. https://doi.org/10.1108/00438020010318073

[3] Broman (2004) Productivity Measurement and its Relationship to Quality in a South African Minting Company. A Research Report Presented to the Graduate School of Business Leadership University of South Africa by Mtotywa M.M.

[4] Mtotywa, M.M. (2007) Productivity Measurement and Its Relationship to Quality in a South African Minting Company.

[5] CBN (2003) Contemporary Economic Policy Issues in Nigeria. CBN Publication, Abuja.

[6] Kishor, K.K. (2016) Productivity and Efficiency Measuremnet Model Developmenet Plants. 3 rd International Conference on Multidisciplinary Research and Practice, 4. 89-95.

[7] Schroeder, R.G. (1985) Operations Management: Decision Making in the Organizations Function. McGraw-Hill, New York.

[8] Etable, L.M., Brigilar, P.F. and Ifurueze, M. (2016) Human Resources Expenditure and Productivity of Universities in Nigeria. Archives of Business Research, 4, 1-9. https://doi.org/10.14738/abr.43.353

[9] Krugman P. (1990) The Age of Diminished Expectations. MIT Press, Cambridge, MASS, p. 9.

[10] Slack, N., Chambers, S. and Johnston, R. (2001) Operations Management. 3rd Edition, Prentice-Hall, Harlow. 
[11] Tangen, S. (2005) Demystifying Productivity and Performance. International Journal of Productivity and Performance Management, 54, 34-46. https://doi.org/10.1108/17410400510571437

[12] Oyeranti, G.A. (2006) Concept and Measurement of Productivity. University of Ibadan, Ibadan.

[13] Alsyouf, I. (2007) The Role of Maintenance in Improving Companies Productivity and Profitability. International Journal of Production Economics, 105, 70-78. https://doi.org/10.1016/j.ijpe.2004.06.057

[14] Helo, P. (2005) Managing Agility and Productivity in the Electronics Industry. Industrial Management \& Data Systems, 104, 567-577. https://doi.org/10.1108/02635570410550232

[15] Wazed, M.A. and Ahmed, S. (2008) Multifactor Productivity Measurements Model (MFPMM) as Effectual Performance Measures in Manufacturing. Australian Journal of Basic and Applied Sciences, 2, 987-996.

[16] Grünberg, T. (2004) Performance Improvement: Towards a Method for Finding and Prioritising Potential Performance Improvement Areas in Manufacturing Operations. International Journal of Productivity and Performance Management, 55, 52-71.

[17] Hoehn, W.K. (2003) Managing Organizational Performance: Linking the Balanced Scored to a Process Improvement Technique. In: Proceeding of the 4 th Annual International Symposium in Industrial Engineering on the Performance-Based Management, Kasetsart University, Bangkok, 1-12.

[18] Andersson, T.D. (1996) Traditional Key Ratio Analysis versus Data Envelopment Analysis: A Comparison of Various Measurements of Productivity and Efficiency in Restaurants. In: Johns, N., Ed., Productivity Management in Hospitality and Tourism, Cassell, London, 209-226.

[19] Fitzsimmons, J.A. and Fitzsimmons, M.J. (1997) Service Management for Competitive Advantage. 2nd Edition, McGraw-Hill, New York.

[20] Witt, C.A. and Witt, S.F. (1989) Why Productivity in the Hotel Sector Is Low. International Journal of Contemporary Hospitality Management, 1, 28-33. https://doi.org/10.1108/EUM0000000001669

[21] Sink, D. (1983) Much Do about Productivity: Where Do We Go from Here. Industrial Engineering, 15, 36-48.

[22] Hannula, M. (2002) Total Productivity Measurement Based on Partial Productivity Ratios. International Journal of Production Economics, 78, 57-67. https://doi.org/10.1016/S0925-5273(00)00186-9

[23] Kontoghiorghes, C. and Gudgel, R. (2004) Investigating the Association between Productivity and Quality Performance in Two Manufacturing Settings. The Quality Management. Journal, 11, 8-20.

[24] Lee, W., Beruvides, M.G. and Chiu, Y.D. (2007) A Study on the Quality-Productivity Relationship and Its Verification in Manufacturing Industries. The Quality Management Journal, 52, 117-139. https://doi.org/10.1080/00137910701328888

[25] Pollitt, D. (2005) Money Controls Cashes in on Continuous Improvement. Training \& Management Development Methods, 19, 207.

[26] Slack, N. (1997) Encyclopaedic Dictionary of Operations Management. Blackwell, Oxford. 
[27] Roa, M.P. (2006) A Performance Measurement System using a Profit-Linked Multifactor Measurement Model. Industrial Management \& Data Systems, 106, 362-379. https://doi.org/10.1108/02635570610653506

[28] Selladurai, R. (2002) An Organizational Profitability, Productivity, Performance (PPP) Model: Going beyond TQM and BPR. Total Quality Management, 13, 613-619. https://doi.org/10.1080/0954412022000002027

[29] Heap, J. (2007) Stormy Productivity Weather Ahead? International Journal Productivity and Performance Measurement, 56, 170-177.

[30] Terzioviski, M. (2006) Quality Measurement Practises and Their Relationship with Customer Satisfaction and Productivity Improvement. Management Research News, 29, 414-424.

[31] Roa, M.P. and Miller, D.M. (2004) Expert Systems Applications for Productivity Analysis. Industrial Management Data Systems, 104, 776-785.

[32] Abdullateef, A. (2014) “Agriculture Category” Daily trust Newspaper. Published on Thursday, 31 July 2014, pp. 7-8. 